\title{
穿通枝領域脳梗塞患者の白質障害と P300の関連について
}

\author{
山下一也 小林 祥泰 木谷 光博 \\ 小出 博巳 岡田 和悟*
}

要旨：慢性期穿通枝領域脳梗塞患者での白質障害, P300潜時, 脳血流 ( $\mathrm{rCBF}$ ) および脳萎縮 の関連について検討を行った，対象は，明らかな痴呆のない慢性期穿通枝領域脳梗塞患者 32 名 (平均年齢62.8歳)で, MRI にて撮影した基底核及び側脳室体部を通る水平断 T2画像上, 脳室 周囲の大脳白質変化 (PVH) の程度により, I 群 : PVH が認められないか前角に薄く限局し たもの 9 名, II 群 : PVH が側脳室体部にも薄く広がるもの11名, III群：PVH が脳室全周に明 らかに認められるか局所的に厚く認められるもの 12 名の 3 群に分類した. 3 群間の P 300 潜時の 比較では, III群では I, II群よりも有意に P300潜時は延長していた. rCBF には 3 群間に有意 差を認めなかった。脳萎縮の比較では, III群では, I, II 群に比し有意に脳萎縮の程度が強かっ た。明らかな痴呆の認められない穿通枝領域脳梗塞患者において, 白質障害の程度と認知機能 障害, 脳萎縮とは関連があることが示唆された。

Key words : white matter changes, P300 latency, regional cerebral blood flow, brain atrophy, cerebral infarction

（脳卒中13：296-300, 1991）

\section{はじめに}

近年, CT や MRI の普及に伴い, 大脳白質病変の検 出ができるようになり, 特に脳室周囲の白質病変, PVL (periventricular lucency) あるいは PVH (periventricular high intensity）が注目を浴びてきている. 既に, 大脳白質病変と痴呆疾患, 高血圧, 老化などと の関係が多数報告されているが, 明らかな痴呆を認め ない穿通枝領域脳梗塞患者において, 大脳の白質障害 が, 知的機能, 脳血流 (rCBF), 脳萎縮とどのような 関連があるかを詳細に検討した報告は少ない、今回, われわれは, 明らかな痴呆を認めない穿通枝領域脳梗 塞患者を対象に, MRI 上での白質障害と事象関連電位 のひとつである $\mathrm{P} 300, \mathrm{rCBF}$, 脳萎縮との関連につい て検討したので報告する。

\section{対象および方法}

対象は, 明らかな痴呆のない（長谷川式簡易知能ス ヶール (HDS) で22点以上) 島根医科大学第 3 内科通

島根医科大学第 3 内科

* 津和野共存病院
院中の慢性期穿通枝領域脳梗塞患者32名 (平均年齢 $62.8 \pm 9.2$ 歳 $($ mean $\pm \mathrm{SD})$, 男性 27 名, 女性 5 名) とし た. 穿通枝領域脳梗塞の診断は, 過去に脳梗塞の既往 を持ち, 全例 CT および MRI 上, 内包, 基底核領域や 放線冠に 1 個 数個の lacunar infarction が認められ るものとし, 大脳皮質を含む梗塞巣も認めるものは除 外した。そのうち, MRI (0.15 Tesla, MRT-15, Toshiba）にて撮影した基底核及び側脳室体部を通る 水平断 $\mathrm{T} 2$ 強調画像上, 脳室周囲の大脳白質变化 (PVH)の程度により, I 群：PVH が認められないか 前角に薄く限局したもの 9 名 (平均年齢 $59.8 \pm 10.2$ 歳, 男性 7 名, 女性 2 名), II 群：PVH が側脳室体部にも 薄く広がるもの11名 (平均年龄61.2 2 9.3 歳, 男性 9 名, 女性 2 名), III群：PVH が脳室全周に明らかに認めら れるか局所的に厚く認められるもの12名 (平均年齢 $66.5 \pm 8.2$ 歳, 男性 11 名, 女性 1 名)の 3 群に分類した. なお， 3 群間に年齢の有意差はみられなかった。それ ぞれの MRI 像を図 $1 \mathrm{~A} ， \mathrm{~B} ， \mathrm{C}$ に示す。

知的機能の評価は HDS と事象関連電位のひとつで ある P300潜時を用いた。 P300測定については, 対象者 に安静仰臥位で, 国際10-20法による Fz, Cz, Pz の 3 部位に活性電極を置き, 両側耳架に基準電極をつけた. 


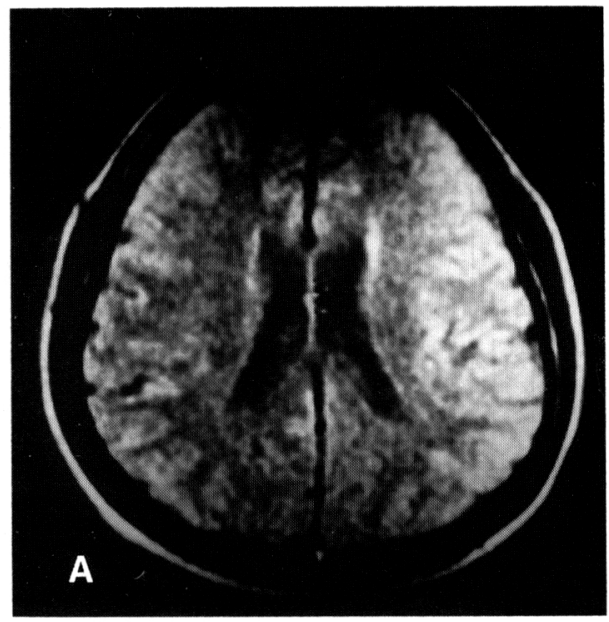

図 $1 \mathbf{A}$ I 群

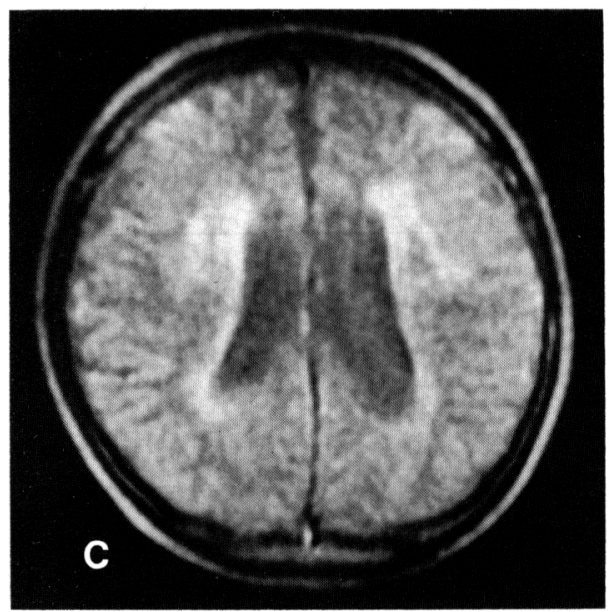

図 1C III群

ヘッドフォーンより $, 1,000 \mathrm{~Hz}$ (刺激頻度 $82 \%$ ) と 2,000 $\mathrm{Hz}$ (刺激頻度 $18 \%$ ) の純音を at random に提示する oddball 課題を用い, 低頻度刺激の音に対してボタン 押しを指示した。それより，得られる脳波の40回平均 加算を行い，医用コンピューター（日本電気三栄， 7 T18)で記録し,これより潜時 $300 \mathrm{msec}$ 付近に出現する 事象関連電位すなわち P300潜時を測定した。

$\mathrm{rCBF}$ は $^{133} \mathrm{Xe}$ 吸入法により, NOVO 社製 $16 \mathrm{ch}$ Cerebrographにて測定した。被験者は仰臥位で検查 室は静寂とし, 閉眼安静を保たせた。左右各 8 個の検 出器を, 気道からの artifact を避けるため副鼻腔を避 けて脳矢状面に垂直に配置した。 rCBF は Fourier 解 析法による $\mathrm{F}_{1}$ 値（灰白質血流量を示す）を用い，全脳

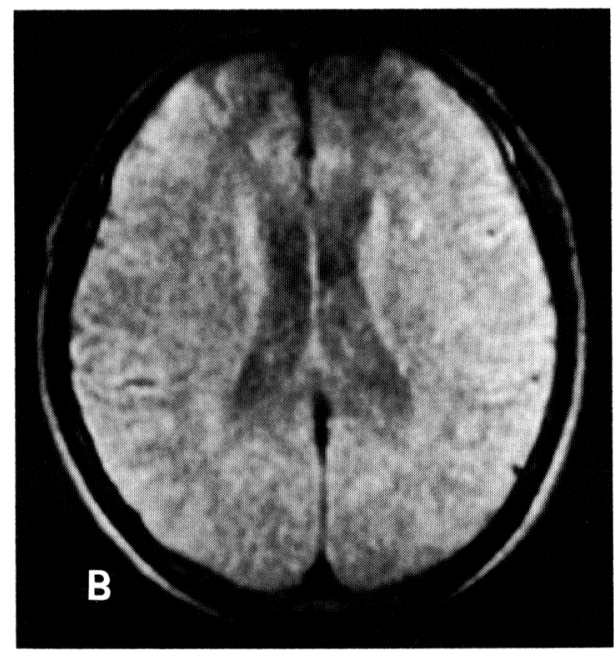

図 1B II 群

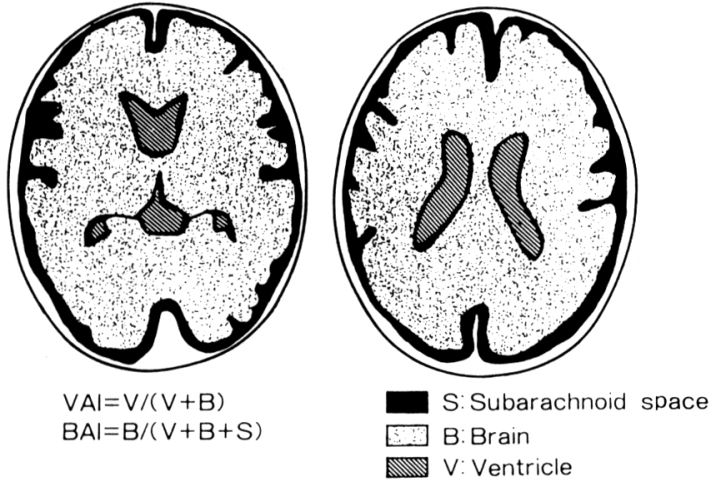

図 2 脳室/脳断面積比 (Ventricular Area Index, VAI)，脳実質/頭蓋内腔断面積比（Brain Atrophy Index, BAI).

平均 $\mathrm{rCBF}$ は左右の脳半球の平均血流值とした。

脳萎縮度の評価は，CTスキャンによる断面積比計 測法である脳室/脳断面積比（Ventricular Area Index, VAI), 脳実質/頭蓋内腔断面積比(Brain Atrophy Index，BAI）を用いだ（図 2 ）。CT スキャンは 東芝CT60A27型および GECT/T8800を用い, canthomeatal lineより $15^{\circ} \mathrm{C}$ のライス面で $0 \sim 10 \mathrm{~cm}$ まで $1 \mathrm{~cm}$ 幅で撮影を行った。そして，X-PLAN 360i(Ushikata）にて，基底核レベルと側脳室体部レベルの CT フィルム上を trace して面積の計測を行い，VAI およ び BAI を算出した，VAI は主に脳室拡大を反映し，ま た，BAI は全脳脊髄液腔の増大すなわち脳室拡大だけ でなく脳表萎縮をも反映する index である1). 


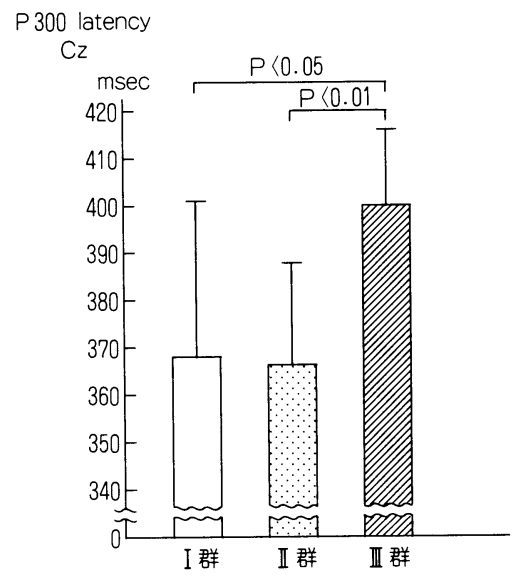

図 3 P300潜時の比較.

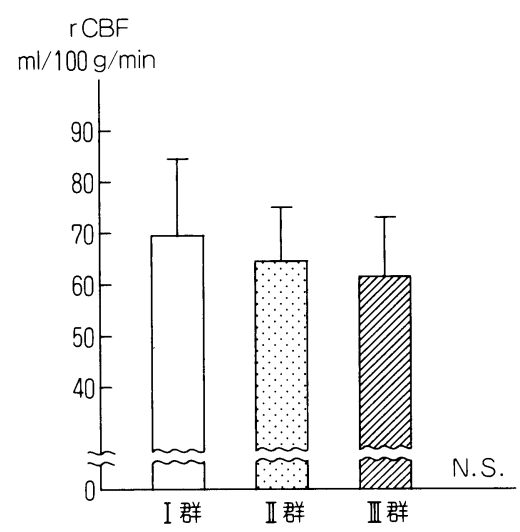

図 $4 \mathrm{rCBF}$ の比較.

N.S. : Not Significant

統計処理は, Student $\mathrm{t}$ test および $\chi^{2}$ 検定を用いた。

\section{結 果}

\section{HDS, P300潜時の比較}

3 群の HDS の比較では, I 群 $32.2 \pm 1.0$ 点, II 群

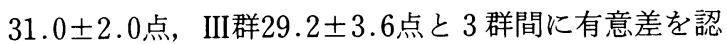
めなかった. しかし, 図 3 に示すように, P300潜時 $(\mathrm{Cz})$ の比較では, I 群 $370.2 \pm 37.0 \mathrm{msec}$, II 群 $371.8 \pm 72.1$ msec, III群 $403.0 \pm 17.3 \mathrm{msec}$ と, P300潜時ではIII群は I，II群よりも有意に延長していた（それぞれ $\mathrm{p}<$ $0.05, \mathrm{p}<0.01)$.

\section{2. rCBF の比較 (図 4)}

$\mathrm{rCBF}$ は, I 群 $69.2 \pm 15.4 \mathrm{~m} l / 100 \mathrm{~g} / \mathrm{min}, \mathrm{II}$ 群 $64.7 \pm$ $9.8 \mathrm{ml} / 100 \mathrm{~g} / \mathrm{min}$, III群 $61.4 \pm 11.8 \mathrm{ml} / 100 \mathrm{~g} / \mathrm{min}$ であ り，3 群間に有意差を認めなかった.
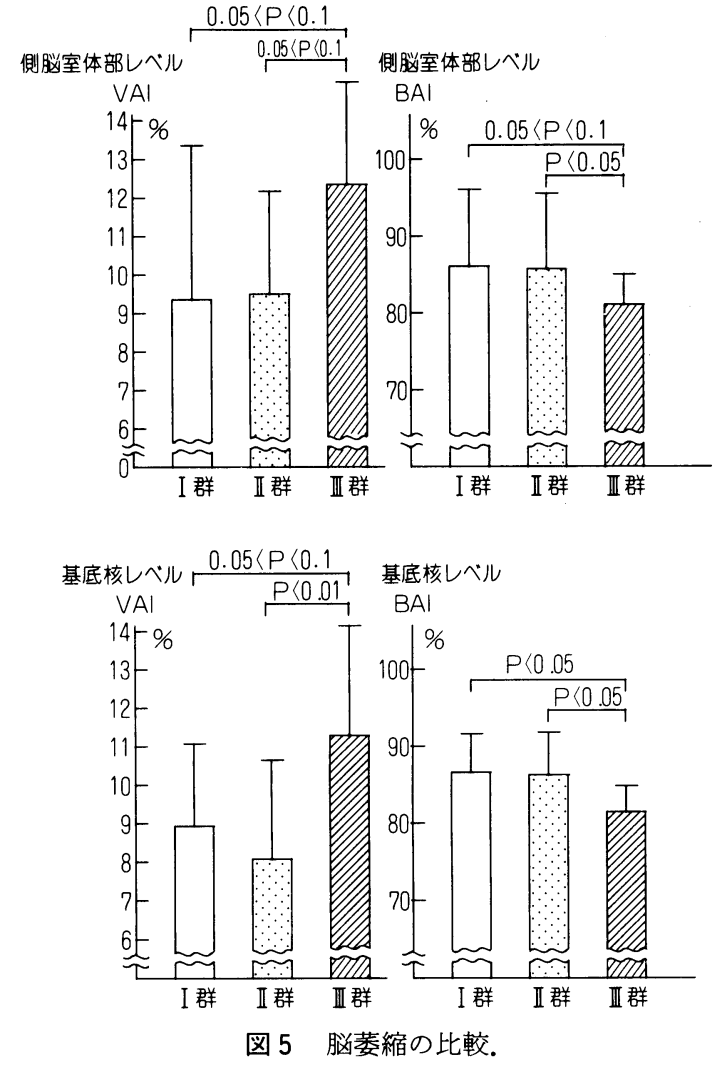

3. 脳萎縮の比較 (図 5 )

脳萎縮の比較では, III群では, I, II群に比し有意 に脳萎縮の程度が強く, 白質障害が強いと脳萎縮も高 度であることが示された。

\section{4.その他のパラメーターの比較}

平均血圧, 高血圧の既往歴, 血清脂質, hematocrit 值等には， 3 群間に有意差を認めなかった。

\section{考察}

白質障害が知的機能にどのような影響を与えるかの 検討は, 血管性痴呆や Alzheimer 病などでは既に数多 くなされている. Steingart らでは, Alzheimer 病を 含む痴呆患者113名を対象に, CT上みらる leukoaraiosis が知的機能に関連あるか否かを検討した。 そ の結果, leuko-araiosis がみられる39例の方がみられ ない74例よりも知的機能が低かったとしている.また， Fukuda $5^{3)}$ は, 血管性痴呆患者では痴呆のない穿通枝 領域脳梗塞患者よりも MRI 上での leuko-araiosis の 計測にて, leuko-araiosis の程度が有意に強いことを 報告している。しかし，健常成人についての CT 上で 
の leuko-araiosisの有無でみた検討では, leukoaraiosis $と$ cognitive capacity screening examinationでみた認知機能については関連を認めないとす る報告4)もなされている。同様に Rao ら ${ }^{5)}$ も健常成人 50名を対象に, leuko-araiosis と認知機能を検討した 結果，両者には関連がみられなかったとしており，わ れわれも既に健常老人 39 名を対象に, MRI 上での白質 障害と知的機能との関連について検討したところ, 白 質障害と知的機能とはあまり関連がみられなかったこ とを報告6)した。

このよらに, leuko-araiosis と知的機能と必ずしも 関連について一致していないが，これらの報告では， 認知機能の評価法自体がまちまちであることを考慮す る必要がある. 今回の検討では, 認知機能について脳 の情報処理能力や短時記憶能力などを反映する客観的 指標として事象関連電位の一つである P 300 潜時を用 いたことが特徴である．P 300 とは，被検者が特定の低 頻度感覚刺激に注意を傾け，それを弁別する際に，刺 激から約 $250 \sim 500 \mathrm{msec} に$ 出現する後期陽性脳電位を いう。この $\mathrm{P} 300$ は各種精神疾患, 痴呆などの評価や診 断に用いられるようになり，すでにわれわれも穿通枝 領域脳梗塞患者に扔いて, P300潜時と脳血流, 知的機 能などとの関連について報告78899)してきた。今回のわ れわれの検討では, 明らかな痴呆のない穿通枝領域脳 梗塞患者に拈いて白質障害の程度と HDS とは関連が なかったが, P300潜時とは, 白質障害が強い患者では, P300潜時がより延長していた。このことは, 白質障害 が潜在性の認知機能の低下と関連があることを示して いる。

脳梗塞患者で leuko-araiosis と脳循環, 脳萎縮との 関連についての報告は少ない。福内は ${ }^{101}$ 多発脳梗塞患 者10例を対象に CT 上の PVL と $\mathrm{rCBF}$, 脳萎縮との間 には明らかな関連がみられなかったと報告している。 一方, Kobari ら ${ }^{11} は$ は, leuko-araiosis を認める症例に $\mathrm{Xe}-\mathrm{CT}$ 法で rCBF を測定し, 対照群に比し皮質, 基底 核, 前頭葉白質での有意な血流低下を認めたことより, leuko-araiosis は全般的な血流低下, 特に脳室周囲白 質の血流低下と関連しているとしている。さらに, Kobari らの健常成人を対象にした検討4)では, leukoaraiosis は年齢だけでなく脳萎縮の程度との間にも関 連を認めている. 今回の検討では, leuko-araiosis が高 度の症例では二次元法にて測定した脳萎縮が leukoaraiosis を認めないかもしくは軽度の症例よりも強 かったが, $\mathrm{rCBF} の$ 比較では有意な差を認めなかった。
これらのことより，明らかな痴呆のない穿通枝領域脳 梗塞では, rCBFがまだ保たれている時期より, leukoaraiosis が次第に出現し，深部白質掞よびその皮質領 域での神経細胞機能の障害を起こし， 2 次的な脳萎縮 として反映されるものと思われる。

白質障害の原因としては，今までにいくつかの因子 が検討され，年齢，脳卒中の既往があること，高血圧， 糖㽷病, 契煙, 高脂血症および心疾患などが重要とさ れている ${ }^{12)}$ 。を，小林ら ${ }^{13)}$ は, Binswanger 病以外の 血管性痴呆に打いて白質障害の程度と血圧，ことに拡 張期血圧と有意な相関が認められたことを報告してい る. 今回の検討では，特に leuko-araiosis と危険因子 については各群での差は認めなかった。

今回の検討より，明らかな痴呆を認めない穿通枝領 域脳梗塞患者を対象に, leuko-araiosis と知的機能, 脳 萎縮の関連が示唆され，慢性期脳梗塞患者においては 脳循環代謝改善薬, 抗血小板薬などの治療が疾呆への 進行を防ぐ上で必要と思われる。

本研究にあたり, 御協力を戴いた島根難病研究所の村尾 光好技師および今岡ゆ久婹に深謝します。

本論文の要旨は第 16 回日本脳卒中学会総会 (平成 3 年 3 月, 大阪）にて発表した.

\section{文献}

1）木谷光博, 小林祥泰, 山口修平ら：CT scanによ る大脳の加齢性萎縮の検討一Digitizer による断 面積比を用いて一. CT 研究 $6: 659-666,1984$

2) Steingart A, Hachinski VC, Lau C, et al: Cognitive and neurologic findings in demented patients with diffuse white matter lucencies on computed tomographic scan (leuko-araiosis). Arch Neurol $44:$ 36-39, 1987

3) Fukuda H, Kobayashi S, Okada K, et al : Frontal white matter lesions and dementia in lacunar infarction. Stroke $21: 1143-1149,1990$

4) Kobari M, Meyer JS, Ichijo M: Leukoaraiosis, cerebral atrophy, and cerebral perfusion in normal aging. Arch Neurol 47: 161-165, 1990

5) Rao SM, Mittenberg W, Bernardin L, et al: Neuropsychological test findings in subjects with leukoaraiosis. Arch Neurol 46: 40-44, 1989

6）山下一也, 小林祥泰, 福田 準ら：健常高路者の大 脳白質障害と知的機能, 血圧の関連について. 日老 
医誌 (in press)

7）山下一也, 小林祥泰, 岡田和悟ら：脳梗塞患者の P300 と脳血流の関連について。脳卒中 $12: 288$ $-292,1990$

8）山下一也, 小林祥泰, 岡田和悟ら：脳梗塞患者の P300 と長谷川式簡易知能スケールの関連につい て。 日老医誌 $27: 74-75,1990$

9）山下一也, 小林祥泰, 岡田和悟ら：穿通枝領域脳梗 塞患者の P300 潜時と局所脳血流の関連について. 臨床神経（in press）

10）福内靖男: 多発脳梗塞患者に打ける知的機能々 CT スキャン所見および脳循環。厚生省痴呆疾患 対策調查研究費, 平成元年度研究報告書,【3】痴呆 疾患の治療法開発に関する研究, pp43-47, 1990
11) Kobari M, Meyer JS, Ichijo M, et al : Leukoaraiosis : Correlation of MR and CT findings with blood flow, atrophy, and cognition. Am J Neuroradiol $11: 273-281,1990$

12) Lechner $H$, Schmidt $R$, Bertha $G$, et al : Nuclear magnetic resonance image white matter lesions and risk factors for stroke in normal individuals. Stroke $19: 263-265,1988$

13）小林祥泰, 福田 準, 岡田和悟ら：穿通枝領域多発 性梗塞における白質障害と血圧及び知的機能との 関連. 厚生省疾呆疾患対策調査研究費, 平成元年度 研究報告書,【3】痴呆疾患の治療法開発に関する研 究, pp111-120, 1990

\title{
Abstract \\ White matter changes and P300 latency in patients with cerebral infarction in the territory of the deep perforators
}

\author{
Kazuya Yamashita, M.D., Shotai Kobayashi, M.D., Mitsuhiro Kitani, M.D., \\ Hiromi Koide, M.D. and Kazunori Okada, M.D.* \\ Third Division of Internal Medicine, Shimane Medical University \\ *Tsuwano Kyozon Hospital
}

We studied the relationship between white matter changes and P300 latency, regional cerebral blood flow $(\mathrm{rCBF})$, and cerebral atrophy in patients with cerebral infarction in the territory of the deep perforators.

Thirty-two nondemented patients ( 27 males, 5 females, mean age 62.8 years) with chronic cerebral infarction in the territory of the deep perforators were divided into three groups by the severity of their white matter changes on MRI. Group I had either no or mild white matter lesions, group II had moderate white matter lesions and group III had severe white matter lesions. Although there were no significant differences among the three groups in the Hasegawa's intelligence scale, P300 latency in group III was significantly longer than that in groups I and II. There were no significant differences among the three groups in $\mathrm{rCBF}$. The severity of brain atrophy was greater in group III than in groups I and II.

It is concluded that white matter lesions are related to cognitive functions and cerebral atrophy in nondemented patients with cerebral infarction in the territory of the deep perforators.

(Jpn. J. Stroke 296-300, 1991) 